\title{
Redaksioneel tot die T.F.J. Dreyer Huldigingsbundel
}

\begin{abstract}
Author:
Ernest van Eck ${ }^{1,2}$

Affiliations:

${ }^{1}$ Department of New

Testament Studies, University

of Pretoria, South Africa

${ }^{2}$ Chairperson of HTS

Teologiese Studies/

Theological Studies Editorial

Board, South Africa

Correspondence to:

Ernest van Eck

Email:

ernest.vaneck@up.ac.za

Postal address:

Faculty of Theology,

University of Pretoria,

Lynwood Road, Hatfield

0083, Pretoria, South Africa

How to cite this article:

Van Eck, E., 2011,

'Redaksioneel tot die T.F.J.

Dreyer Huldigingsbundel',

HTS Teologiese Studies/

Theological Studies 67(3),

Art. \#1124, 6 pages. http://

dx.doi.org/10.4102/hts.

v67i3.1124
\end{abstract}

C 2011. The Authors.

Licensee: AOSIS

OpenJournals. This work

is licensed under the

Creative Commons

Attribution License.
Ter erkenning van Theuns

Dreyer

Hierdie Huldigingsbundel word opgedra aan prof. Theuns Dreyer vir sy toegewyde diens in die Nederduitsch Hervormde Kerk van Afrika (NHKA) die afgelope 40 jaar op beide akademiese en kerklike terrein. 'Opgedra' in hierdie konteks beteken nie 'dankie' nie. Die rede hiervoor is eenvoudig. Geen blyk van waardering kan uitdrukking

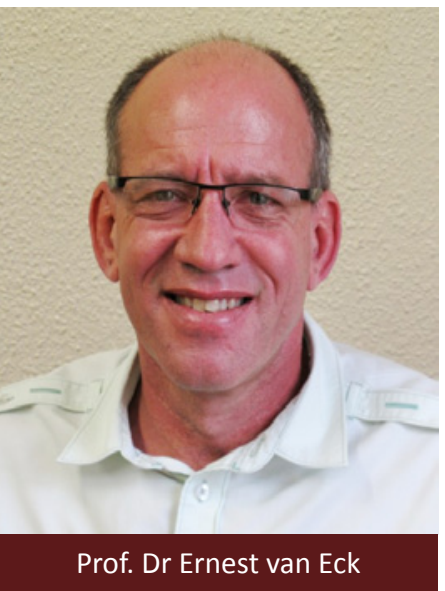

In honour of Theuns Dreyer This dedication is in hounor of Prof. Theuns Dreyer for his devoted service for more than 40 years to the Netherdutch Reformed Church of Africa (NRCA), both in the academic and clerical fields. 'Dedicated' in this context does not mean 'thank you', simply because no token of appreciation can express the Church's gratitude for having been blessed with a person of his talents for the past 40 years. Theuns Dreyer's gee aan die dankbaarheid van die Kerk dat God 'n persoon met sy gawes vir die Kerk vir die afgelope 40 jaar gegee het nie. Theuns Dreyer se liefde vir die kerk en die Heer van die kerk loop soos 'n fyn draad deur sy hele loopbaan as predikant en akademikus. Daarom was niks ooit te veel gevra nie, al het dit by tye sterk inbreuk gemaak op persoonlike en familietyd. Hiervoor sê die Kerk dankie.

Reeds as 'n jong predikant was dit duidelik dat hy diep spore in die Kerk sou trap. $\mathrm{Na}$ 'n tydperk van twee jaar in sy eerste gemeente vertrek hy vir verdere studie in Praktiese Teologie na Nederland, waar hy binne die bestek van twee jaar promoveer. In 1983, nege jaar en vier gemeentes later, word hy aangestel as professor en Hoof van die Departement Praktiese Teologie aan die Universiteit van Pretoria (Afdeling A). In 2000, die jaar waarin die twee Fakulteite van Teologie aan die Universiteit van Pretoria saamsmelt het, word hy aangestel as die Hoof van die Hervormde Teologiese Kollege met as opdrag die praktiese vorming van studente van die Kerk en die voortgesette toerusting van predikante van die Kerk. Laasgenoemde aanstelling het hom uitmuntend gepas, omdat dit hom die geleentheid gebied het om teorie en praktyk singewend tot ' $n$ eenheid te bring in die vorming en toerusting van studente en predikante.

As akademikus het prof. Dreyer veral uitnemende bydraes gelewer op die terrein van die teoretiese basis van die Praktiese Teologie as teologiese dissipline, die prediking, bedieningstrukture en spiritualiteit. Wat die love for the church and the Lord of the church runs like a thin line through his entire career as a minister and academic. For this reason, nothing that was asked of him was ever too much, even though at times it infringed on private and family time. For this, the Church wants to thank him.

Even as a young minister, it was clear that he would leave his mark on the Church. After a term of two years with his first congregation, he left for the Netherlands to further his studies in Practical Theology, and proceeded to obtain his doctorate within a matter of two years. In 1983, nine years and four congregations later, he was appointed as Professor and Head of the Department of Practical Theology at the University of Pretoria (Section A). In 2000, the year in which the two faculties of theology at the University of Pretoria merged, he was appointed as Head of the Reformed Theological College, with as mission the practical formation of the church's students and the continued equipping of ministers of since it gave him the opportunity to merge theory and practice into a meaningful cohesion in order to train, develop and equip students and ministers.

As an academic, Prof. Dreyer made distinguished contributions particularly with regard to the theoretical basis of Practical Theology as theological discipline, homiletics, ministerial structures, and spirituality. As far as the formulation of theory in Practical Theology as theological discipline is concerned, he is of the opinion that there should indeed be an the church. This position suited him perfectly, 
teorievorming in Praktiese Teologie as teologiese dissipline betref, oordeel hy dat daar inderdaad 'n wisselwerking behoort te wees tussen die empiriese en teologiese vertrekpunte in die beoefening van die dissipline. Hierdie wisselwerking is egter nie simmetries nie; in die beoefening van die dissipline moet daar altyd teruggevra word na Bybelse inhoude om 'n sinvolle wisselwerking tussen teorie en praktyk daar te stel. Sy navorsing op die gebied van die prediking druk sy stempel sterk op die predikante van die NHKA af. Dreyer, deur onder meer gebruik te maak van die insigte van Gadamer en Ebeling, definieer die prediking as 'n pneumatiese Woordgebeure - 'n gebeure wat bestaan uit die begeleiding van gelowiges tot 'n ontmoeting met God via 'n Skrifteks. Hy lê klem op wat hy die kerugmatiese struktuur van die prediking noem, te wete dat in die prediking aandag gegee moet word aan die indikatiewe en die imperatiewe wat moontlik opgesluit lê in Skrifgedeeltes wat in die prediking aan die orde kom. Prediking, in kort, kan nie gegrond wees in 'n kerugmatiese model wat klem lê op die outoriteit van die prediker nie. Verkondigers van die Woord moet nie poog om lidmate te probeer oortuig nie, maar moet eerder getuig van die Skrif se werking in hul eie lewens. Prediking, vir Dreyer, is dus 'kenosis', 'n getuienis waarvan die egtheid afhang van die verkondiger se eie geloofsbelewenis en meelewing met die kerk. Logies is sy standpunt dan ook dat erediensvernuwing nie los van die prediking kan geskied nie. Wat betref die bedieningstrukture in die NHKA was Dreyer ook rigtinggewend. Reeds so vroeg as 1987 bevraagteken hy die herder-kudde-model, wat toe die dominante model van bediening in die gemeentes van die NHKA was, krities. In die plek van die herder-kudde-model stel hy die nou bekende liggaamsmodel voor as 'n meer verantwoordbare bedieningspatroon in die gemeentes van die NHKA. Gemeentelike bediening moet nie áán lidmate nie, maar sáám met lidmate plaasvind, veral deur middel van diensgroepe en werkgroepe in die gemeente. Dit is nie die predikant se verantwoordelikheid om alles in die gemeente te doen nie. Wat die predikant egter wel behoort te doen, is om lidmate te bemagtig deur toerusting en die prediking, sodat lidmate mekaar en die wêreld kan dien. Hiermee saam stel hy voor dat gemeentes dit moet oorweeg om 'n bedieningsplan vir die predikant daar te stel wat voldoen aan die behoeftes van die spesifieke gemeente. Hierdie voorstelle is nie sonder teenkanting ontvang nie, maar is vandag die werkwyse in die gemeentes van die Kerk. Wat die NHKA se verstaan van sy etos betref, het hy ook 'n rigtinggewende bydrae gelewer. Die etos van 'n kerk het nie te make met die betrokke kerk se gebruike en tradisies nie, maar met 'n diepliggende saak, te wete teologiebeoefening. Die etos van 'n kerk word gevorm deur die wyse waarop daardie kerk teologies besig is met die Skrif. In die NHKA, as voorbeeld, oordeel hy dat dit die NHKA se Bybels-Reformatoriese teologie is wat aan die Kerk 'n bepaalde etos gee - 'n etos wat op sy beurt weer tot uitdrukking kom in ' $n$ bepaalde spiritualiteit en identiteit. Hieruit is dit duidelik dat hy van oordeel is dat 'n kerk altyd bereid moet wees om solidêr-krities met sy etos en tradisies om te gaan. interaction between the empirical and theoretical points of departure in the pursuit of the discipline. This interaction, however, is not symmetrical; the pursuit of the discipline must always revert to Biblical content in order to establish a meaningful interaction between theory and practice. His research in the field of homiletics has had a strong influence on ministers of the NRCA. Dreyer, by employing the insights of Gadamer and Ebeling, amongst others, defines preaching as a pneumatic Word-event - an event which comprises the accompaniment of believers to encounter God via a Bible text. He emphasises what he calls the kerygmatic structure of preaching, namely that preaching must heed the indicatives and imperatives that may be enclosed in the passages of Scripture that comes under discussion in the service. Preaching, in brief, cannot be founded in a kerygmatic model which emphasises the authority of the preacher. Proclaimers of the Word should not endeavour to convince members of the congregation, but should rather be a witness of the Word's action in his or her own life. Thus, for Dreyer preaching is 'kenosis', a witness of which the authenticity depends on the proclaimer's own religious experience and involvement in the church. It follows that renewal of the church service cannot occur in isolation of preaching. As far as the structures of ministry in the NRCA are concerned, Dreyer also proved to be a guiding influence. Even as early as 1987 he questioned the shepherd-flock model, at the time the dominant model for pastorate in NRCA congregations. In lieu of the shepherd-flock model he proposed the now familiar body model as a more accountable pattern of ministry in NRCA congregations. Congregational ministry should not be ministry performed to the congregation, but should be a ministry that is undertaken with members, especially through the congregation's service groups and task groups. It is not the minister's responsibility to do everything in the congregation. What the minister should do, however, is to empower members of the congregation through equipping and preaching, thereby enabling members to serve one another and the world. He proposes that concurrent with this approach congregations should consider creating a ministry plan for the minister, which is in line with the particular needs of the specific congregation. These proposals were not received without opposition, but today they constitute the method in the Church's congregations. As far as the NRCA's understanding of her ethos is concerned, his contribution again proved to be directional. A church's ethos is not about the particular church's customs and traditions, but about a very profound matter, namely theological practice. A church's ethos is shaped by the way in which that church occupies herself theologically with the Bible. In the case of the NRCA, for example, Dreyer holds the opinion that the Church owes her particular ethos to the NRCA's BiblicalReformative theology. In turn, this ethos is expressed in a particular spirituality and identity. Arising from this view, he maintains that a church, in dealing with her ethos and traditions, must always be prepared to do so in a solidarycritical manner. 
Op die kerklike terrein het hy'n onmeetbare bydrae gelewer. Hy het op verskeie rade en komitees van die Kerk gedien waar hy waardevolle insette lewer wat betref die Kerk se finansies, versorging van predikante en behoeftiges, evangelisasie, en erediens en prediking. As Hoof van die Hervormde Teologiese Kollege aan die Universiteit van Pretoria bou hy die Kollege uit tot 'n onmisbare faset van die Kerk se dienslewering aan studente, predikante en die gemeenskap. Die studente vir wie hy klasgee praat met groot waardering van sowel die inhoud as die aanbieding van sy lesings. In sy lesings, aldus sy studente, is dit duidelik dat kritiese denke en geloof nie uitsluitend is nie. Ook vloei daar ' $n$ menigtal populêr-wetenskaplike werk uit sy pen. Net met die lees van die opskrifte daarvan is dit duidelik dat hy telkens in tye wat dit nodig was die Kerk oor verskeie sake met nugterheid van advies bedien het en tot kalmte en rustigheid gemaan het.

Dit is egter veral sy werk as lid van die Kommissie van die Algemene Kerkvergadering wat vermeld moet word. Hy dien vir meer as die helfte van sy predikantsloopbaan (van 21 jaar) op die Kommissie, en as voorsitter vir drie van sy sewe verkose termyne. Dit is veral in hierdie hoedanigheid waar sy liefde vir die Kerk duidelik blyk en hy na vore getree het as gerespekteerde kerkleier na wie daar opgesien word. As kerkleier het hy nooit geskroom om aan te pas waar en wanneer dit nodig was nie, altyd met respek vir die kerk se tradisies. Ook sy ireniese persoonlikheid staan uit, sowel as sy vermoë om konflik om te los. Sy kennis van die Kerk en die Kerkorde is buitengewoon, asook sy vermoë tot samevatting en die gee van rigting.

Met hierdie Huldigingsbundel word erkenning gegee aan ' $n$ besondere akademikus en kerkmens. Die hoop word uitgespreek dat sowel die akademie as die kerk vir nog lank van sy gawes gebruik sal kan maak. Ook word hy nou 'n nodige ruskans gegun - wat hy min tydens die afgelope jare gehad het.

Die Redaksie van die HTS Teologiese Studies is geëerd om hierdie Huldigingsbundel aan hom op te dra!

Prof. Dr E. van Eck

Voorsitter: Redaksie HTS Teologiese Studies
The contribution he made to the NRCA is invaluable. He served on several boards and committees of the Church, where he gave valuable input pertaining to the Church's finances, care for ministers and the poor, evangelism, the church service and preaching. As Head of the Reformed Theological College at the University of Pretoria, he expanded the College into an indispensable facet of the Church's service to students, ministers and the community. Students attending his classes have great appreciation for both the content and the presentation of his lectures. According to his students, his lectures clearly show that critical thinking and faith are not mutually exclusive. Numerous popular-scientific works also flowed from his pen. A mere glance at their titles, gives a clear indication that he had given sound advice to the Church when it was needed, pleading for calm and restraint.

What needs to be highlighted in particular is his work as member of the Commission of the General Church Synod. For more than half of his career as a minister (for 21 years) he has served on the Commission, of which three of his seven elected terms as Chair. It is in this capacity in particular that his love for the Church is evident, and he distinguished himself as a highly regarded church leader to whom people looked up to. As a church leader he never hesitated to adapt where and when necessary, always with respect for the church's traditions. His irenic personality is a distinguishing trait, so too is his ability to resolve conflict. His knowledge of the Church and the Church Order is exceptional, also his ability to summarise and to give direction.

With this dedication, recognition is given to an exceptional academic and church person. It is hoped that both academia and the church will still be able to benefit from his talents for a long time. We wish him a well-deserved break and time to rest - something that had rarely happened in the past.

The Editorial Board of the HTS Theological Studies is honoured to dedicate this publication to him!

Prof. Dr E. van Eck

Chairperson: Editorial Board HTS Theological Studies 


\section{BYLAAG 1}

\section{Theunis Frederik Jacobus Dreyer - Curriculum Vitae}

\section{Gebore}

08 Desember 1946, Potchefstroom, Suid-Afrika

\section{Opleiding}

D.Theol. (Praktiese Teologie), 1974, Proefskrif: J.J. van Oosterzee as homileet (18171882), Rijksuniversiteit Utrecht (Nederland).

B.D. (Teologie), 1969, Universiteit van Pretoria.

B.A., 1966, Universiteit van Pretoria.

\section{Professionele posisies}

Hoof, Hervormde Teologiese Kollege, Universiteit van Pretoria, 2000-2011

Departementshoof, Departement Praktiese Teologie, Fakulteit Teologie (Afd A), Universiteit van Pretoria, 1983-2000

Volle professor in Praktiese Teologie, Fakulteit Teologie (Afd A), Universiteit van Pretoria, 1983-2000

Gemeentepredikant, Hartebeestpoort, 1977

Gemeentepredikant, Voortrekkerhoogte, 1976

Gemeentepredikant, Noord-Rand, 1974

Gemeentepredikant, Krugersdorp-Noord/Noord-Rand, 1971

Pastorale hulp, Gemeente Newlands, 1970

Gasdosent, African Institute for Missiology, 1993-2007

\section{Toekennings}

HCM Fourie Erepenning, 2007

\section{Lidmaatskap van prosessionele liggame}

Prakties-Teologiese Werkgemeenskap van Suid, 1976-

Lid van Suid-Afrikaanse Akademie vir Wetenskap en Kuns, 1989-

\section{Nagraadse studente}

Studieleier van 7 voltooide doktorale proefskrifte en 15 meester verhandelinge

\section{Universiteitsloopbaan}

Diensmedalje, Universiteit van Pretoria, 1969

Ondervoorsitter, Van der Hoff Teologiese Vereniging, 1969

Voorsitter, Hervormde Studentevereniging, 1968

Ondervoorsitter, Huiskomitee: Voortrekkertehuis, 1968

Voorsitter, Pleinkomitee (Sentrale Joolkomitee), 1967

\section{Kerklike rade en kommissies}

Voorsitter, Kommissie van die Algemene Kerkvergadering, 1998-2004, 2007-2010 Visevoorsitter, Kommissie van die Algemene Kerkvergadering, 1992-1998 Skriba, Kommissie van die Algemene Kerkvergadering, 1991-1992

Raad van Finansies, 1990-2004

Direksie van HAUM, 1990-1994

Vise-skriba, Kommissie van die Algemene Kerkvergadering, 1989-1991

Lid van die Kommissie van die Algemene Kerkvergadering, 1986-1989

Direksie van Kinderhuise van die Nederduitsch Hervormde Kerk van Afrika, 1986-1989

Raad vir Herderlike Sorg, 1983-1986

Raad vir Evangelisasie, 1983-1986

Algemene Diakonale Raad, 1983-1986

Voorsitter, Ring van Rustenburg, 1980-1983

Voorsitter, Predikantevergadering, 1980-1983

Kuratorium, 1980-1983

Raad vir Prediking en Erediens, 1979-1986

\section{Openbare liggame}

Skoolkomitee, Tegniese Hoërskool N. Diedericks, 1971-1973

Bestuursraad, Laerskool Brits, 1982-1987

Bestuursraad, Hoërskool Hartbeespoort, 1990-1995

Skoolraad, Brits, 1984-1986

\section{Wetenskaplike publikasies Boeke}

1974, J.J. van Oosterzee as homileet (1817-1882), Utrecht, Elinkwijk.

1981, Poimeniek: 'n Pastorale oriëntasie, Kital, Pretoria.

\section{Bydraes in boeke}

1981, 'Die vrou en die ampte', in P.S. Dreyer (red.), 'n Deugsame vrou, pp. 55-63, HAUM, Pretoria.

2010, 'Voorwoord deur die voorsitter van die Kommissie van die Algemene Kerkvergadering van die Nederduitsch Hervormde Kerk van Afrika', in 'Honderd Jaar Kerk en Teologiese Opleiding: 'n Kroniek van die Hervormde Kerk', HTS Teologiese Studies/Theological Studies, suppl. 9, 66(3), Art. \#943, 1 page. http://dx.doi. org/10.4102/hts.v66i3.943

\section{Wetenskaplike artikels in vaktydskrifte}

1980, 'Die studieveld van die Praktiese Teologie', Die kerk se werk, pp. 1-9.

1984, 'Proefskrifbespreking, S.G.A. Golden, Dialogies - kommunikatiewe prediking', Hervormde Teologiese Studies 40(3), 119-120.

1984, 'Die noodsaaklike onderskeiding tussen pastoraat en evangelisasie ten opsigte van die probleem van kerklosheid en kerkloosheid', Hervormde Teologiese Studies 40(1), 73-81.

1984, 'Die verband tussen prediking/erediens en die lewe van die gemeente', Hervormde Teologiese Studies 40(4), 107-124.

1985, 'Die dogmatiese binding van die prediking', Hervormde Teologiese Studies 41(3) 378-286.

1986, 'Politieke en sosiale vraagstukke in die prediking', Hervormde Teologiese Studies 42(3), 464-484

1987, 'Die homiletiek van Karl Barth', Hervormde Teologiese Studies 43(1\&2), 121-137. 1987, "n Prakties - Teologiese evaluering van moontlike bedieningstrukture in die Nederduitsch Hervormde Kerk, toegespits op die rol van die predikant', Hervormde Teologiese Studies 43(3), 522-555.

1988, 'Die 'kanon' in die kanon as probleem vir die prediking', Hervormde Teologiese Studies 44(2), 314-328.

1989, " $n$ Poging tot ' $n$ herdefinisie van die prediking binne die raamwerk van die Reformatoriese teologie', Hervormde Teologiese Studies 45(2), 350-369.

1991, 'Eerste treë in die Praktiese Teologie - Waarheen?', Hervormde Teologiese Studies, 47(3), 597-608.

1992, 'Die “De Wet-era" en daarna', Hervormde Teologiese Studies 48(1\&2), 427-441.

1992, 'Kategismusprediking in die Nederduitsch Hervormde Kerk van Afrika', Hervormde Teologiese Studies 48(3\&4), 743-758.

1994, 'Kerugmatiese struktuur as bolwerk teen moralisme in die prediking', Hervormde Teologiese Studies 50(1\&2), 281-295.

1994, 'Liturgiese koorsang as wyse van kerklike verkondiging: 'n Prinsipiële besinnin vanuit hermeneuties - homiletiese perspektief', Hervormde Teologiese Studies 50(3), 583-660.

1994, 'Verkennende studie met die oog op die identifisering en kategorisering van leerteorieë met verwysing na die prediking', Hervormde Teologiese Studies 50(3), 687-712.

1995, ' Invloed van metateorieë op basisteorieë in die beoefening van die Praktiese Teologie', Hervormde Teologiese Studies 51(1), 207-223.

1995, 'Implikasies van die kommunikatiewe handelingsteorie vir'n prakties - teologiese perspektief op die ekklesiologie', Hervormde Teologiese Studies 51(3), 792-805.

1996, 'Belangrikheid van besoeke aan nuwe intrekkers as deel van die werkprogram van die gemeentepredikant', Hervormde Teologiese Studies 52(1), 130-146.

1996, 'Praktiese kerkwees in die nuwe Suid-Afrika', Hervormde Teologiese Studies 52(1), 179-189.

1996, 'Prediking en kultuur', Hervormde Teologiese Studies 52(4), 820-832.

1997, 'Implikasies van die Handves van Menseregte op die pastorale versorging van die homoseksueel', Hervormde Teologiese Studies 53(1\&2), 353-371.

1997, 'Verhouding prediking - belydenis in 'n postmoderne Konteks: 'n “Huwelik"of "saamwoon"?', Hervormde Teologiese Studies 53(4), 1250-1265.

1998, 'Spiritualiteit, identiteit en die etos van die Nederduitsch Hervormde Kerk', Hervormde Teologiese Studies 54(1\&2), 289-314.

1998, 'Kommunikasiekrag van liturgiese simbole met spesifieke verwysing na die toga', Hervormde Teologiese Studies 54(3\&4), 687-735. 
1998, 'Satanisme gesien vanuit ' $n$ pastorale perspektief', Hervormde Teologiese Studies 54(3\&4), 736-759.

1999, 'Prof dr MJ du P Beukes: 'n Terugblik op sy lewe en werk', Hervormde Teologiese Studies 55(2\&3), 285-304.

2000, (mede-outeur, Smith, W.), 'Pastoraat in rousmart as bewuste kommunikasie van die emosies van rousmart', Hervormde Teologiese Studies 56(1), 273-294.

2000, (mede-outeur, Smith, W.), 'Godsbegrippe en die funksie van metafore in die rousmartproses', Hervormde Teologiese Studies 56(1), 295-213.

2002, (mede-outeurs, Venter, P.M \& Dreyer, Y.), 'Geloofskommunikasie in 'n pluriforme wêreld', HTS Teologiese Studies 58(3), 973-993.

2002, (mede-outeur, Maritz, J.F.), "n Ondersoek na die aanwending van musiek as hulpmiddel in pastorale terapie binne ' $\mathrm{n}$ gespreksmodel', Hervormde Teologiese Studies 58(3), 1208-1220.

2003, 'Statistieke vertel ' $n$ storie: 'n Visie vir die Hervormde Kerk op pad na 2010', Hervormde Teologiese Studies 59(4),1045-1062.

2004, 'Huldigingswoord', Hervormde Teologiese Studies 60(1\&2), 1-5.

2004, 'Kenotiese prediking - die katalisator vir liturgiese verdieping in die huidige Konteks', Hervormde Teologiese Studies 60(1\&2), 93-108.

2004, (mede-outeur, Dreyer, T.F.), Erotiese oordrag en teenoordrag as psigologiese fenomeen in 'n pastorale relasie', Hervormde Teologiese Studies 60(1\&2), 155-173.

2004, 'God die Allerhoogste woon nie in mensgemaakte konstruksies nie', Hervormde Teologiese Studies 60(3), 665-672.

2005, 'Preaching and culture', Hervormde Teologiese Studies 61(3), 793-808.

2006, 'Die akkommodering en bestuur van diversiteit in gemeenteverband', HTS Teologiese Studies/Theological Studies 62(4), 1291-1309.

2005, (mede-outeur, Botha, P.J.), 'Die benutting van vraelyste met die oog op meer effektiewe toerusting tydens huweliksvoorbereiding', Hervormde Teologiese Studies 62(4), 1527-1542.

2007, 'Karl Barth as homilist', Hervormde Teologiese Studies 63(4), 1473-1491.

2008, 'Die Universiteit van Pretoria se eeufeesviering in 2008: Woorde van gelukwense deur die Nederduitsch Hervormde Kerk van Afrika/The University of Pretoria's centenary celebration in 2008: A message of congratulation from the Netherdutch centenary celebration in 2008: A message of congratulation from the
Reformed Church of Africa', Hervormde Teologiese Studies 64(1), 5-6.

2008, 'Die kerk, die huwelik en seks - 'n morele krisis', Hervormde Teologiese Studies 64(1), 483-496.

2009, "n Kerk met karakter: Die perspektief van Gerben Heitink', HTS Teologiese Studies/Theological Studies 65(1), Art. \#315, $5 \mathrm{http} / / / \mathrm{dx}$.doi.org/10.4102/hts. v65i.315.

2011, “"Wat jy ook op die aarde mag bind, sal in die hemel gebonde wees, en wat jy ook op die aarde mag ontbind, sal in die hemel ontbonde wees" (Matt 16:19)' HTS Teologiese Studies/Theological Studies 67(1), Art. \#914, 4 pages. http://dx.doi. org/10.4102/hts.v67i1.914.

\section{Boekresensies}

1984, Rossouw, P.J., 'Grondlyne van 'n pastorale model - Gerben Heitink', in Hervormde Teologiese Studies 40(2), 184-186.

1984, Heitink, G., 'Gids voor het pastoraat', in Hervormde Teologiese Studies 40(3), 129-131.

1985, Smuts, A.J., 'Die Woord aan die werk', in Hervormde Teologiese Studies 41(3), 503.

1985, Combrink, V., 'Skrifgebruik in pastoraat: Die standpunt van Jay E Adams', in Hervormde Teologiese Studies 44(3), 753-756.

1985, Killinger, J., 'Fundamentals of preaching', in Hervormde Teologiese Studies 44(4), 944-946.

1988, Pieterse, H.J.C., 'Communicative preaching, Pretoria, Universiteit van SuidAfrika', in Hervormde Teologiese Studies 44(4), 946 - 949.

1988, Van Staden, S.M., 'My groei en ontwikkeling as mens', in Hervormde eologiese Studies 44(4), 949-950.

1989, Smuts, A.J. (red.), 'Perspektiewe en pastoraat: Praktiese Teologie in Suid-Afrika (5)', in Hervormde Teologiese Studies 45(4), 980-984.

1989, Lerle, E., 'Kontakstark verkündigen: Grundzüge Bibeltreuer Predigt', in Hervormde Teologiese Studies 47(3), 855-857.

1990, Grey, J., 'Predikant - wees vandag: Praktiese voorstelle vir spesialisering en privatisering deur predikante van die Nederduitse Gereformeerde Kerk', in Hervormde Teologiese Studies 49(1\&2), 337-340.

1993, Pieterse, H.J.C., 'Praktiese Teologie as kommunikatiewe handelingsteorie', in Hervormde Teologiese Studies 51(1), 260-261.

\section{Populêr - wetenskaplike artikels}

1970, 'Verdedigingsobligasies', in Die Hervormer, Mei, p. 6.

1976, 'Huidige kerklike toestand in Nederland en Europa - 'n hermeneutiese probleem', Almanak 70, pp. 10-14.

1979, 'Die Kerkganger en die prediking', Die Hervormer, Augustus, p. 4.

1980, 'Gelowig wees: Saam met of sonder die kerk', Die Hervormer 72(3), p. 3.
1980, 'Gelowig wees: Met of sonder die Kerk?', Die Hervormer 72(4), p. 12.

1982, 'Kerk en gelowige in 1982', Die Hervormer 73(10), pp. 1, 4.

1982, 'Die eise van ,n kameraadskaphuwelik', Die Christelike Vrou, Junie, p. 8.

1982, 'Diens van barmhartigheid in Skrif en praktyk', Die Hervormer 74(3), p. 14.

1982, 'Positiewe bydrae oor Christelike erediens: "soek die Here in sy tempel"', Die Hervormer 75(4), p. 14.

1983, 'Nuus uit gemeentes: Nageslag van Thomas Dreyer trek saam', Die Hervormer 75(6), p. 7.

1983, 'Waarom gaan dit in die okkulte?: “Okkultisme”', Die Hervormer 75(8), p. 14.

1984, 'Kerk na Pinkster - of Pinksterkerk?', Die Hervormer 76(4), p. 1.

1985, 'Gebedshouding in die erediens', Die Hervormer 77(3), p. 4.

1986, 'Voorbereiding vir die erediens', Die Hervormer 77(11), p. 8.

1986, 'Begin en afsluiting van die erediens', Die Hervormer 78(3), p. 7.

1986, 'Skriflesing en prediking', Die Hervormer 78(4), 7.

1988, 'Dr Johannes Dreyer', Almanak 82, pp. 39-40.

1988, 'Praktiese Teologie meer as net oefensessies', Die Hervormer 79(10), p. 10.

1988, 'Praktiese Teologie - kroon van die Teologie', Die Hervormer 79(11), p. 7.

1988 , 'Pastoraat - een van die grootste uitdagings aan die predikant', Die Hervormer

80(1), p. 7.

1988, 'Geld nog steeds die wortel van die kwaad', Die Hervormer 80(6), p. 5.

1988, 'Prediking en die kuns van gesprekvoering', Die Hervormer 80(6), p. 9.

1988, 'Kategismusprediking. Onbekend maak onbemind', Die Hervormer 80(8), p. 4.

1989, 'Rentekoers - beleid maak van ons mense slawe', Die Hervormer 80(10), p. 3.

1990, 'Vroeëre professore aan die fakulteit: Prof dr Jl de Wet', Almanak 86, pp. 48-49.

1990, 'Wyle mev. A.E. van der Merwe', Almanak 84, pp. 52-53.

1990, 'Gebed vir ons tyd', Die Hervormer 83(11), p. 4.

1990, 'Gelowiges werk deur diakonaat, nie diensorganisasies', Die Hervormer 83(15), p. 3.

1990, 'Preekpraatjies: Prediking in die brandpunt', Konteks 1(1), p. 21.

1990, 'Preekpraatjies: Prediking is die Woord van God (1)', Konteks 1(2), p. 21.

1990, 'Preekpraatjies: Prediking is die Woord van God (2)', Konteks 1(3), p. 28.

1990, 'Preekpraatjies: Is prediking die Woord van God (3)', Konteks 1(4), p. 28.

1990, 'Preekpraatjies: Prediking begelei die mens tot 'n ontmoeting met God', Konteks $1(5)$, p. 28.

1990, 'Preekpraatjies: Prediking as kommunikasie', Konteks 2(6), p. 28.

1990, 'Preekpraatjies: Aktuele prediking', Konteks 1(7), p. 28.

1990, 'Preekpraatjies: Kinders en preke', Konteks 1(8), p. 28.

1990, 'Preekpraatjies: Hoor en verstaan', Konteks 1(9), p. 28.

1991, 'Vooruitskouing 1991: Toekoms lê in God se hande', Die Hervormer 83(19), p. 4.

1991, 'Preekpraatjies: Vir wie word gepreek?' Konteks 2(1), p. 28.

1991, 'Preekpraatjies: Gewilde preke', Konteks 2(2), p. 28.

1991, 'Preekpraatjies: Gesprek na die preek', Konteks 2(3), p. 42.

1991, 'Inspraak: Oujaarsdienste? Vraag en antwoord' Konteks 2(5), pp. 5-6.

1991, 'Ons lesers se opinies: Ring spreek kommer uit oor onderwys', Die Hervormer 84(7), p. 4

1991, 'Kommentaar: Uiteenlopende gesigspunte oor die plek van die kind in die erediens', Hervormer 84(13), pp. 3, 8 .

1992, 'Droogtes - Normaal of abnormaal?', Die Hervormer 85(5), p. 3.

1992, 'Dr DJC van Wyk - 15 jaar redakteur van die Hervormer', Konteks 3(6), p. 6.

1992, 'Ons voorgangers: Prof JI (Koos) de Wet', Konteks 3(9), p. 9.

1992, 'Vroeëre professore aan die Fakulteit: Prof dr Jl de Wet', Almanak 86, pp. 48-49. 1993, 'Kerk na binne en/of na buite gerig', Die Hervormer 85(20), p. 4.

1994, 'Kerk en huisgesin: Oordenking (Lees Matteus 7:21 - 28)', Almanak 88, pp. 170172

1994, 'Aktuele sake aan die kerklike en teologiese front', Die Hervormer 86(22), p. 5.

1994, 'Aktuele sake aan die kerklike en teologiese front: Só sal barmhartigheid tot sy reg kom', Die Hervormer 87(16), p. 5.

1994, 'Insamelingsprojekte moet die Kerk waardig wees', Die Hervormer 87(17), p. 1.

1994, 'Gesinsjaar: Totale pastorale sorg aan die gesin', Konteks 5(10), pp. 34-35.

1994, 'Gesinsjaar: Huisbesoek aksentueer die gesin', Konteks 5(11), pp. 32-33.

1994, 'Gesinsjaar: Kerklike bediening vanuit die perspektief van die gesin', Konteks 5(12), pp. 31-32.

1994, 'Gesprek tussen twee kerke dek 'n wye veld', Die Hervormer 86(23), pp. 1-2.

1994, 'Prinsipiële standpunte oor die kerklied', Die Hervormer 87(8), pp. 1, 5.

1995, 'Woord - en - liedbyeenkoms kan nie die erediens vervang nie', Die Hervormer $87(22)$, p. 8. 
1995, 'Televisie - uitsendings', Die Hervormer 88(2), p. 2.

1995, 'Kerk sal opnuut moet besin oor onderwys', Die Hervormer 88(4), pp. 1, 6 1995, 'Mense en gebeure in ons Kerk: Buitelandse besoek en navorsing oor teologiese opleiding', Die Hervormer 88(7), p. 2.

1995, 'Algemene Kerkvergadering 1995 'n waterskeiding', Die Hervormer 88(8), p. 1.

1995, 'Mense en gebeure in ons Kerk: Bronkhorstspruit bevestig sy tradisie', Die Hervormer 88(10), p. 2.

1995, 'Eietydse getuienis of 'n outydse strydgeskrif', Die Hervormer 88(15), pp. 5-6.

1995, 'Getuienis of strydgeskrif', Die Hervormer 88(16), pp. 5, 8.

1995, 'Prof JP Oberholzer word vereer met eredoktorsgraad', Die Hervormer 88(17), p. 1

1995, 'Redakteur tree na agtien jaar uit', Die Hervormer 88(18), p. 3.

1996, 'Lewensketse: Ampsdraers en lidmate. Mev Dirkie Naudé', Almanak, 90, pp. 169-170.

1996, 'Ouderling se taak in die huidige samelewing', Die Hervormer 89(1), p. 3.

1997, 'Lewensketse: Ampsdraers en lidmate - Ds WP van der Merwe', Almanak 91, pp. 149-150.

1997, 'Terugblik op die Algemene Kerkvergadering', Die Hervormer 90(9), pp. 1, 8.

1997, 'Praktiese Teologie', Konteks 8(11), p. 9.

1998, 'Predikante - vyftigjarige ampsbediening: Ds TF Dreyer ', Almanak 92, pp. 149150.

1998, 'In verhouding met God', Die Hervormer 90(20), p. 1.

1998, 'Kerklike eenheid stuit teen verskille oor kerklike identiteit', Die Hervormer 90(21), p. 3.

1998, 'Etos van die Nederduitsch Hervormde Kerk', Die Hervormer 90(22), pp. 5, 8

1998, 'Teologiese opleiding en spiritualiteit', Die Hervormer 91(1), p. 5.

1998, 'Verleentheid of geleentheid?', Die Hervormer 92(3), pp. 1, 3.

1998, 'Alternatiewe bedieningsmoontlikhede', Die Hervormer 91(4), pp. 5, 8.

1998, 'Getuienis van die Nederduitsch Hervormde Kerk aan die owerheid', Die Hervormer 91(10), p. 1.

1999, 'Optimisme ten spyte van moeilike omstandighede', Die Hervormer 92(5), p. 1.

1999, 'Hervormer 1899 - 1999: Groeteboodskap', Die Hervormer 92(13\&14), p. 3.

1999, 'Hervormer 1899 - 1999: Armeversorging - 31 Maart 1937', Die Hervormer 92(13\&14), p. 6.

1999, 'Nuwejaarsboodskap: Gebed en gebod', Konteks 10(1\&2), p. 8

1999, 'NHSV Kongres ... wat van binne af uit 'n mens kom, dit maak 'n mens onrein', Konteks 10(8), pp. 8, 12.

2000, 'Nuwe millennium', Die Hervormer 92(19), p. 1.

2000, 'Hervormde Teologiese Kollege', Die Hervormer 92(20), p. 3.

2000, '10 Jaar Feesuitgawe: Verjaardagboodskappe', Konteks 11(4), pp. 8-9.

2001, 'Roudiens - dr AJG Dreyer', Konteks 12(3), pp. 7-9.

2001, 'Kerk en Teologie 2001 - Geloofsbelydenis van Nicea: Wat ter wille van ons, die mense, en ter wille van ons saligheid neergedaal het uit die hemel.....', Die Hervormer 93(21), p. 5.

2001, 'Welwees van pastoriepare', Die Hervormer 94(2), p. 2.

2001, 'Lig uit die Woord: Romeine 1: 1- 7-Genade en vrede vir julle', Die Hervormer 94(2), p. 4.
2001, 'Leierskap in die Kerk', Die Hervormer 94(8), p. 1.

2001, 'Lig uit die Woord: Kolossense 4:2 -6 - Bid vir ons', Die Hervormer 94(12), p. 4. 2002, 'Inspraak: 350 jaar Gereformeerd', Konteks 13(6), p. 10.

2002, 'Inspraak: Groeteboodskap - kinderhuise', Konteks 13(8), p. 6.

2003, 'Lof van God: Emeritaat - dr DJC van Wyk', Die Hervormer 96(12), pp. 1-2.

2003, 'HTK - Preekwerkgroep', Die Hervormer 96(12), p. 3.

2004, 'Verwonderd oor sy koms', Konteks 14(11). pp. 4-5.

2004, 'Boodskappe vir 2004', Konteks 15(1\&2), p. 13.

2004, 'Afskeidswoord aan dr Paul de Beer', Konteks 15(12), p. 10.

2004, 'Redaksioneel: Na die verkiesing - kom ons emigreer', Die Hervormer 97(2),

p. 4.

2004, 'Hervormde Teologiese Kollege vind diep inslag', Die Hervormer 97(4), p. 2.

2004, 'Hervormde Teologiese Kollege 'n groot aanwins', Die Hervormer 97(5), pp. 2, 6.

2004, 'Hervormde Kerk en teologie in die een en twintigste eeu: God woon nie in mensgemaakte konstruksies nie, Die Hervormer 97(14), pp. 5-6, 8.

2005, 'Briewe van ons lesers.... Misdaad: Wat sê die Bybel?', Die Hervormer 98(20), p. 3.

2006, 'Gedagtes uit die Woord: Hebreërs 7: 22 - 28 - Jesus se offer bly vir ewig', Die Hervormer 98(21), p. 4.

2006, 'Kerkeenheid in postmoderne idioom', Die Hervormer 99(10), p. 6.

2007, 'Toekoms van die kerk die volgende honderd jaar - Erediens', Almanak 101, pp. 147-149.

2007, 'Reaksie op die HCM Fourie-Stigting. Is dit 'n teologiese modaliteit?', Die Hervormer 99(20), pp. 3, 6.

2008, 'Kerkjaar: Epifanie', Konteks 19(1), pp. 4-5.

2008, 'Kerkjaar: Lydenstyd/Goeie Vrydag. Ons is vrygespreek', Konteks 19(2), pp. 4-5.

2008, 'Kerkjaar: Opstanding/Dankdag vir die Oes. Van verootmoediging na verwondering', Konteks 19(3), pp. 4-5.

2008, 'Kerkjaar: Hemelvaart -'n 'weggaan', Konteks 19(4), pp. 4-5.

2008, Kerkjaar: Pinkster - sonder liefde baat dit niks', Konteks 19(5), pp. 84-85.

2008, 'Kerkjaar: Drie-eenheid - Om die onsêbare te sê', Konteks 19(6), pp. 4-5.

2008, 'Kerkjaar: Koninkrykstyd/Bartolomeusnag - Uitbreiding van die Kerk', Konteks 19(7), pp. 4-5.

2008, 'Ons Vader en Koninkrykstyd', Konteks 19(8), pp. 4-5.

2008, 'Kerkjaar. Eindtyd', Konteks 19(9), pp. 6-7.

2008, 'Huldeblyk: Prof FJ van Zyl', e-Hervormer 1(14), pp. 1-2.

2009, 'Agterblad: Gesamentlike verklaring van die drie susterkerke', e-Hervormer 2(5), pp. 6-7.

2009, 'Voorblad: Verklaring van dosente', e-Hervormer 2(7), pp. 1-2.

2009, 'Versoeningsgesprek', e-Hervormer 2(29), p. 3.

2010, '2010 - Saam in diens: Een in versoenende verskeidenheid', Konteks 21(1), p. 6. 2010, 'NHSV 70 jaar', Konteks 21(4) Mei, p. 12.

2010, 'By die Fakulteit: Praktykvorming', Konteks 21(4), p. 19.

2010, 'Algemene Kerkvergadering of referendum?', Konteks 21(8), p. 8; 98(5), p. 2. 